\title{
Evaluation of Anti-anxiety Potential of Tinospora cordifolia (Willd.) Leaf Extract in Mice Using Experimental Models
}

\author{
Gururaja MP1,* , Anjali Krishna M', Himanshu Joshi² \\ 'Department of Pharmacology, NGSM Institute of Pharmaceutical Sciences, NITTE (Deemed to be University), Paneer, Deralakatte, Mangaluru, DK, Karnataka, INDIA. \\ ${ }^{2}$ College of Pharmacy, Graphic Era Hill University, Bhimtal Campus, Uttarakhand, INDIA.
}

\begin{abstract}
Objectives: The present study was conducted to evaluate the anxiolytic potential of ethanolic leaf extract of Tinospora cordifolia Linn. Tinospora cordifolia, the versatile herbal drug is the distinctive source of constituents which is having antidiabetic, immunomodulatory, antioxidant, antimicrobial, antitoxic and anticancer activity. Methods: Leaves of Tinospora cordifolia was collected, dried and powdered used for 7 days cold maceration process. Ethanolic extract was subjected to the preliminary phytochemical screening to analyse the presence of active constituents. At a dose of $100 \mathrm{mg} / \mathrm{kg}, 200 \mathrm{mg} / \mathrm{kg}, 400 \mathrm{mg} / \mathrm{kg}$ body weight of animal was evaluated for antianxiety activity in mice using 3 experimental designs; elevated plus maze, open filed, light/dark transition model. Test group animals were compared with group of animal treated with diazepam $(1 \mathrm{mg} / \mathrm{kg})$ as standard drug. Ethanolic extract at 100,200 , and $400 \mathrm{mg} / \mathrm{kg}$ showed activity in dose dependent manner and at a dose of $400 \mathrm{mg} / \mathrm{kg}$ showed significant increase; in elevated plus maze, number of entries in open arm and time spent in open arm; number of entries into light chamber and time spent in
\end{abstract}

light chamber in light and dark transition model and in open field; number of square crossed, number of rearing and time spent in central square. Results: The results supported traditional use of Tinospora cordifolia in nervous disorders. Conclusion: Study concluded that ethanolic extract of leaves of Tinospora cordifolia at a dose of $400 \mathrm{mg} / \mathrm{kg}$ has significant antianxiety activity.

Key words: Anti-anxiety activity, Diazepam, Elevated plus maze, Light and dark model, Open field Tinospora cordifolia Linn.

Correspondence

Dr. Gururaja MP,

Department of Pharmacology, NGSM Institute of Pharmaceutical Sciences, NITTE (Deemed to be University), Paneer, Deralakatte, Mangaluru, DK-575018, Karnataka, INDIA.

Email id: gurureceptor@gmail.com

DOI: 10.5530/jyp.2022.14.9

\section{INTRODUCTION}

Emotional breakdown, stress and discomfort are commonly seen in the present generation. Anxiety is almost always correlated with many health and medical problems and sometimes is a symptom of mental illness. ${ }^{1}$ Anxiety is mainly due to stress but the possibility to be anxious is linked to genetic factors like trait anxiety. ${ }^{2}$ Some studies have found that people engaged in more physical activities are at reduced risk of anxiety disorder and less prone to serious anxiety symptoms. ${ }^{3}$ Certain drugs also induce anxiety like CNS stimulant, withdrawal of alcohol, drugs and metabolic changes like hyperglycaemia, thyrotoxicosis, hyperventilation. ${ }^{4}$ From the studies it was confirmed that the likely cause of anxiety is the imbalance in brain chemistry. The problems associated with the number of neurotransmitters like norepinephrine, serotonin, GABA are expressed in individuals having anxiety disorders. ${ }^{5}$

Benzodiazepine is one of the common medications for the treatment of general anxiety. Widely prescribed by physicians and used by patients because of their fast start up, effectiveness and tolerance. ${ }^{6}$ It is also prescribed for treating anxiety, acute withdrawal of alcohol, skeletal muscular spasm and seizures. ${ }^{7}$ Benzodiazepines are the $\mathrm{GABA}_{\mathrm{A}}$ receptor modulators. All commonly used benzodiazepines can facilitate the binding to $\mathrm{GABA}_{\mathrm{A}}$ receptors of the key G-aminobutyric acid inhibitors neurotransmitter (GABA), thus increasing ionic currents caused by GABA through conducting channels. ${ }^{8}$ Tinospora cordifolia, the versatile herbal drug is the distinctive source of constituents which is having antidiabetic, immunomodulatory, antioxidant, antimicrobial, antitoxic and anticancer activity. ${ }^{9}$ Number of investigations and research has been done on chemical constituents of guduchi. ${ }^{10}$ It also has potentiating activity on other substances in the form of shodhan - vidhi. "Guduchi" is the Sanskrit name which indicates that one protect from diseases. ${ }^{11}$ In hindu mythology, hindi name of Tinospora cordifolia "giloya" is believed to be the heavenly elixir which prevents aging. ${ }^{12}$

There are many studies which report various therapeutic potential of this herb. However, no published scientific datas are available on the antianxiety activity of leaves of Tinospora cordifolia. Hence the present study was undertaken.

\section{MATERIALS AND METHODS}

\section{Preparation of Extract}

The leaves of Tinospora cordifolia Linn. were collected and shade dried until it was moisture free. The coarse powder of dried leaves was made by using electric grinder. Ethanolic extract of Tinospora cordifolia leaves was prepared by 7 days cold maceration process.

By using solvent ethanol, maceration process was carried out in an extraction chamber. For a period of 7 days the dried coarse powder of leaves and ethanol mixture was kept aside at room temperature along with occasional stirring. After 7 days, the content was filtered by using a muslin cloth. The separated content was kept in boiling water bath to remove ethanol and stored in a desiccator for experimental use.

\section{Preliminary Qualitative Phytochemical Investigation}

Qualitative phytochemical examination of ethanolic leaf extract of Tinospora cordifolia Linn. was performed for identifying the presence of active constituents in it. ${ }^{13}$ Standard methods were followed to perform test. $^{14}$ 
Table 1: Effect of Tinospora cordifolia Linn. ethanolic leaf extract on number of entries and Time spent in open arm in elevated plus maze.

\begin{tabular}{cccc}
\hline SI.No & Groups & $\begin{array}{c}\text { Number of } \\
\text { entries into } \\
\text { open arm } \\
\text { Mean } \pm \text { SEM }\end{array}$ & $\begin{array}{c}\text { Time spent in } \\
\text { open arm } \\
\text { Mean } \pm \text { SEM }\end{array}$ \\
\hline 1 & Control & $1 \pm 0.365^{\mathrm{b}}$ & $6.1 \pm 2.2^{\mathrm{b}}$ \\
2 & Standard & $9 \pm 0.89^{\mathrm{a}}$ & $289 \pm 5.5^{\mathrm{a}}$ \\
3 & Ethanolic test extract $(100 \mathrm{mg} / \mathrm{kg})$ & $2.83 \pm 0.401^{\mathrm{b}}$ & $41.4 \pm 5.7^{\mathrm{b}}$ \\
4 & Ethanolic test extract $(200 \mathrm{mg} / \mathrm{kg})$ & $3.6 \pm 0.55^{\mathrm{b}}$ & $52.3 \pm 7.4^{\mathrm{b}}$ \\
5 & Ethanolic test extract $(400 \mathrm{mg} / \mathrm{kg})$ & $7.2 \pm 1.39^{\mathrm{a}}$ & $137 \pm 17^{\mathrm{a}}$ \\
\hline
\end{tabular}

All the values are expressed as mean $\pm \operatorname{SEM}(n=6) . \mathrm{a}=p<0.05$ when compared with control, $\mathrm{b}=p<0.05$ when compared with standard. $P<0.05$ was considered as statistically significant.

Table 2: Effect of Tinospora cordifolia Linn. Ethanolic leaf extract on number of entries and time spent in light chamber in light /dark transition model.

\begin{tabular}{cccc}
\hline SI.No & Groups & $\begin{array}{c}\text { Number of } \\
\text { entries into } \\
\text { light chamber } \\
\text { Mean } \pm \text { SEM }\end{array}$ & $\begin{array}{c}\text { Time spent } \\
\text { in light } \\
\text { chamber } \\
\text { Mean } \pm \text { SEM }\end{array}$ \\
\hline 1 & Control & $2 \pm 0.516^{\mathrm{b}}$ & $22 \pm 2.92^{\mathrm{b}}$ \\
2 & Standard & $22.5 \pm 2.09^{\mathrm{a}}$ & $433 \pm 41.51^{\mathrm{a}}$ \\
3 & Ethanolic test extract $(100 \mathrm{mg} / \mathrm{kg})$ & $3.1 \pm 0.65^{\mathrm{b}}$ & $51.9 \pm 5.29^{\mathrm{b}}$ \\
4 & Ethanolic test extract $(200 \mathrm{mg} / \mathrm{kg})$ & $6 \pm 0.44^{\mathrm{b}}$ & $90 \pm 8.56^{\mathrm{b}}$ \\
5 & Ethanolic test extract $(400 \mathrm{mg} / \mathrm{kg})$ & $13 \pm 1.064^{\mathrm{a}}$ & $222.8 \pm 17.9^{\mathrm{a}}$ \\
\hline
\end{tabular}

All the values are expressed as mean $\pm \operatorname{SEM}(n=6) . \mathrm{a}=p<0.05$ when compared with control, $\mathrm{b}=p<0.05$ when compared with standard. $P<0.05$ was considered as statistically significant

Table 3: Effect of Tinospora cordifolia Linn. Ethanolic leaf extract on number of rearing, Number of square crossed and Time spent in central square in open field.

\begin{tabular}{ccccc}
\hline SI.No & Groups & $\begin{array}{c}\text { Number } \\
\text { of square } \\
\text { crossed in } \\
\text { open field } \\
\text { Mean } \pm \text { SEM }\end{array}$ & $\begin{array}{c}\text { Number of } \\
\text { rearing in } \\
\text { open field } \\
\text { Mean } \pm \text { SEM }\end{array}$ & $\begin{array}{c}\text { Time spent in } \\
\text { central square } \\
\text { Mean } \pm \text { SEM }\end{array}$ \\
\hline 1 & Control & $78 \pm 6.93^{\mathrm{b}}$ & $7.1 \pm 1.07^{\mathrm{b}}$ & $15.5 \pm 6.10^{\mathrm{b}}$ \\
2 & Standard & $190.3 \pm 12.8^{\mathrm{a}}$ & $31.6 \pm 3.37^{\mathrm{a}}$ & $355 \pm 29.1^{\mathrm{a}}$ \\
3 & $\begin{array}{c}\text { Ethanolic test } \\
\text { extract (100 mg/kg) }\end{array}$ & $101 \pm 10.63^{\mathrm{b}}$ & $13.1 \pm 1.19^{\mathrm{b}}$ & $58.7 \pm 8.1^{\mathrm{b}}$ \\
4 & $\begin{array}{c}\text { Ethanolic test } \\
\text { extract (200 mg/kg) }\end{array}$ & $119 \pm 9.6^{\mathrm{b}}$ & $16.4 \pm 1.16^{\mathrm{b}}$ & $115 \pm 2.63^{\mathrm{b}}$ \\
5 & $\begin{array}{c}\text { Ethanolic test } \\
\text { extract (400 mg/kg) }\end{array}$ & $127.4 \pm 8.43^{\mathrm{a}}$ & $24 \pm 1.69^{\mathrm{a}}$ & $216.3 \pm 14.01^{\mathrm{a}}$ \\
\hline
\end{tabular}

All the values are expressed as mean $\pm \operatorname{SEM}(n=6)$. $a=p<0.05$ when compared with control, $\mathrm{b}=p<0.05$ when compared with standard. $P<0.05$ was considered as statistically significant.

\section{Evaluation of Anti-anxiety Activity Dosing}

Antianxiety potential of leaves of Tinospora cordifolia Linn was evaluated by 3 dose levels.

$1 / 10^{\text {th }}$ of the higher dose in acute oral toxicity trails was the mid dose i.e, $1 / 10^{\text {th }}$ of $2000 \mathrm{mg} / \mathrm{kg}-200 \mathrm{mg} / \mathrm{kg}$ of body weight of animal. Double the $1 / 10^{\text {th }}$ of dose will be the higher dose i.e, $400 \mathrm{mg} / \mathrm{kg}$ of mice body weight. The lower dose was half of the $1 / 10$ th dose which was $100 \mathrm{mg} / \mathrm{kg}$ of the mice body weight. Albino mice of approximately 20-30g was divided into five classes of 6 animal each.

\section{Elevated Plus Maze}

Exploratory behavior, anxiety characters and motor activity were assessed by using elevated plus maze. ${ }^{15}$ The apparatus is about $25 \mathrm{~cm}$ height from the ground level, consists of 2 open arm $(16 \times 5 \mathrm{~cm})$ and 2 closed arm $(16 \times 5 \mathrm{~cm})$ which are extended from common central arena. ${ }^{16}$ Individual animals from each group of animals were placed at central platform by facing to open arm. ${ }^{17,18}$ Group I was orally treated with $0.6 \% \mathrm{w} / \mathrm{v}$ CMC. Diazepam $(1 \mathrm{mg} / \mathrm{kg})$ i.p treated animals served as group II. For 7 consecutive days, group III, group IV, group V was treated with ethanolic leaf extract at a dose of $100 \mathrm{mg} / \mathrm{kg}, 200 \mathrm{mg} / \mathrm{kg}, 400 \mathrm{mg} / \mathrm{kg}$. On $8^{\text {th }}$ day, $1 \mathrm{hr}$ after administration of standard and ethanolic extract in each groups, individually mice were placed in central platform of apparatus facing open arm. The parameters assessed for evaluation of activity during 5 min of test duration was evaluated by using ORCHIDAll maze video tracking software. ${ }^{19}$

\section{Light and Dark Transition Test}

The light/dark apparatus is divided into two chambers $(40 \mathrm{~cm} \times 60 \mathrm{~cm}$ $\times 20 \mathrm{~cm})$. The light chamber is white in colour and separated from dark chamber by a wall which is connected with a small opening at bottom..$^{20}$ 20-30g weighing albino mice were divided into 5 groups, each group having 6 animals. Group I was orally treated with $0.6 \% \mathrm{w} / \mathrm{v}$ CMC. Diazepam $(1 \mathrm{mg} / \mathrm{kg})$ i.p treated animals served as group II. For 7 consecutive days, group III, group IV, group V was treated with ethanolic leaf extract at a dose of $100 \mathrm{mg} / \mathrm{kg}, 200 \mathrm{mg} / \mathrm{kg}, 400 \mathrm{mg} / \mathrm{kg}$. On $8^{\text {th }}$ day, $1 \mathrm{hr}$ after administration of standard and ethanolic extract in each groups, individually mice were placed over illuminated area of chamber, ${ }^{21}$ and the parameters such as time spent in light chamber of the cage and number of entries in illuminated chamber is been noted for 10 min duration.

\section{Open Field Model}

Open field apparatus is a wooden box of dimension $40 \mathrm{~cm} \times 40 \mathrm{~cm} \times 30 \mathrm{~cm}$. Apparatus consists of 16 squares of equal size and central zone is marked to separate squares from others. Lamp of $60 \mathrm{~W}$ is suspended $100 \mathrm{~cm}$ above the apparatus. ${ }^{22}$ Group I was orally treated with $0.6 \% \mathrm{w} / \mathrm{v}$ CMC. Diazepam $(1 \mathrm{mg} / \mathrm{kg})$ i.p treated animals served as group II. For 7 consecutive days, group III, group IV, group V was treated with ethanolic leaf extract at a dose of $100 \mathrm{mg} / \mathrm{kg}, 200 \mathrm{mg} / \mathrm{kg}, 400 \mathrm{mg} / \mathrm{kg}$. On $8^{\text {th }}$ day, $1 \mathrm{hr}$ after administration of standard and ethanolic extract in each groups, individually mice were placed in central zone of apparatus, 10 min of test duration evaluated parameters such as number of rearing, number of square crossed and time spent in central square. ${ }^{23}$

\section{Statistical Analysis}

All the data were expressed as mean $\pm \operatorname{SEM}(n=6)$ and analyzed by one-way ANOVA followed by post hoc Schiff's test using SPSS software version 10 . $P$ value less than 0.05 was considered as statistically significant. 


\section{RESULTS}

\section{Phytochemical Analysis}

The preliminary qualitative phytochemical analysis performed revealed the presence of flavanoid, saponins and proteins.

\section{Effect of Ethanolic Extract of Leaf of Tinospora cordifolia (Willd) in Mice Elevated Plus Maze Model (Table 1)}

\section{a) Number of Open Arm Entries}

The group of animals treated with standard drug (diazepam $1 \mathrm{mg} / \mathrm{kg}$ ) showed significant increase $(p<0.05)$ in open arm of elevated plus maze, compared to other groups. While assessing the exploratory behavior, ethanolic extract at dose $100 \mathrm{mg} / \mathrm{kg}, 200 \mathrm{mg} / \mathrm{kg}$ and $400 \mathrm{mg} / \mathrm{kg}$ exhibited activity in dose dependent manner. High dose $400 \mathrm{mg} / \mathrm{kg}$, significantly increased $(p<0.05)$ entries into open arm.

\section{b) Time Spent in Open Arms}

Significant increase $(p<0.05)$ in time spent in open arm by the standard drug treated group (diazepam $1 \mathrm{mg} / \mathrm{kg}$ ) compared to control group. The ethanolic extract of Tinopspora cordfolia at a dose of $100 \mathrm{mg} / \mathrm{kg}, 200 \mathrm{mg} / \mathrm{kg}$, $400 \mathrm{mg} / \mathrm{kg}$ exhibit the potential in dose dependent manner. High dose $400 \mathrm{mg} / \mathrm{kg}$ showed significant increase $(p<0.05)$ of time spent in open arm.

\section{Light and Dark Transition Test (Table 2)}

\section{a) Number of Entries into Light Chamber}

There was a significant increase $(p<0.05)$ in entries into light chamber by the group of animal treated with diazepam $(1 \mathrm{mg} / \mathrm{kg})$ as standard drug. At a dose of $100 \mathrm{mg} / \mathrm{kg}, 200 \mathrm{mg} / \mathrm{kg}, 400 \mathrm{mg} / \mathrm{kg}$ it showed increase in number of entries in light chamber in dose dependent manner and $400 \mathrm{mg} / \mathrm{kg}$ exhibited significant increase $(p<0.05)$ in activity.

\section{b) Time Spent in the Light Chamber}

When compared to control group, the standard drug (diazepam $1 \mathrm{mg} / \mathrm{kg}$ ) treated group of animals showed significant increase $(p<0.05)$ in time spent in light chamber. It was found that test extract of dose 100, 200 and $400 \mathrm{mg} / \mathrm{kg}$ exhibit exploratory potential in dose dependent manner. Ethanolic extract of high dose $400 \mathrm{mg} / \mathrm{kg}$ showed significant increase $(p<0.05)$ in time spent in light chamber compared to other groups.

\section{Open Field Test (Table 3)}

\section{a) Number of Square Crossed}

Significant increase $(p<0.05)$ in number of square crossed in open field was observed in the group of animals treated with diazepam $(1 \mathrm{mg} / \mathrm{kg})$ as standard drug. At a dose $100 \mathrm{mg} / \mathrm{kg}, 200 \mathrm{mg} / \mathrm{kg}$ and $400 \mathrm{mg} / \mathrm{kg}$ of ethanolic extract showed number of square crossed in dose dependent manner and $400 \mathrm{mg} / \mathrm{kg}$ showed significant increase $(p<0.05)$ in number of square crossed in open field comparing to other dose.

\section{b) Number of Rearing}

There was a significant increase $(p<0.05)$ in number of rearing showed by group of animals treated with diazepam $(1 \mathrm{mg} / \mathrm{kg})$ as standard drug. Number of rearing showed by test group animals at a dose of $100 \mathrm{mg} /$ $\mathrm{kg}, 200 \mathrm{mg} / \mathrm{kg}, 400 \mathrm{mg} / \mathrm{kg}$ in dose dependent manner. Ethanolic extract of $400 \mathrm{mg} / \mathrm{kg}$ exhibit significant $(p<0.05)$ activity in number of rearing.

\section{c) Time Spent in the Central Square}

Group of animals treated with diazepam $(1 \mathrm{mg} / \mathrm{kg})$ as standard drug showed significant increase $(p<0.05)$ in time spent in central square of open field. Ethanolic test extract of dose $100 \mathrm{mg} / \mathrm{kg}, 200 \mathrm{mg} / \mathrm{kg}$ and $400 \mathrm{mg} / \mathrm{kg}$ showed activity in dose dependent manner and high dose $(400 \mathrm{mgkg})$ of ethanolic extract exhibit significant increase $(p<0.05)$ in time spent in central square of open field.

\section{DISCUSSION}

The results from the present study showed that ethanolic extract of leaves of Tinospora cordifolia possessed significant anti-anxiety activity in dose dependent manner. Investigation on Tinospora cordifolia stem, leaf, whole plant part confirmed the vast medicinal properties. ${ }^{24}$ The experimental model elevated plus maze is commonly used for the screening of anxiolytic drugs. ${ }^{25}$ In many other experimental models the elevated plus maze exhibits more acceptance than Y-maze, radial maze. Anxiolytic and anxiogenic drugs successively identified by using this models. ${ }^{26}$ Chemical/extract having anti-anxiety activity shows increase in number of entries into open arm and time spent in open arm. The anxiolytic property is exerted through $\mathrm{GABA}_{\mathrm{A}}$ receptor complex and evaluated by using diazepam $(1 \mathrm{mg} / \mathrm{kg})$ as standard drug. ${ }^{27}$ Study was conducted by 7 days consecutive oral treatment of ethanolic extract at a dose of $100,200,400 \mathrm{mg} / \mathrm{kg}$ and on $8^{\text {th }}$ day of dosing, after $1 \mathrm{hr}$ animals are placed in elevated plus maze showed anxiolytic property by increase in number of open arm entry and time spent in open arm. Activity is confirmed by comparing parameters with control group.

In light/dark transition model, animal spent more time in dark chamber than in light chamber due to fear for facing new environmental condition. ${ }^{28}$ Parameters such as; number of entries into light chamber and time spent in light chamber are assessed for the evaluation of antianxiety property. ${ }^{29}$ The ethanolic leaf extract of Tinospora cordifolia at a dose of $100,200,400 \mathrm{mg} / \mathrm{kg}$ was given orally to mice of respective groups for 7 days. After $1 \mathrm{hr}$, of oral administration on $8^{\text {th }}$ day activity was evaluated by keeping animal on model. The antianxiety activity exhibited by increase in number of entries and time spent in light chamber as compared to the control treated group.

In open field, animal shows emotional disturbance, fear and anxiety. Animals having anxiety spent more time towards outer zone, corners/ peripheral arenas of the open field. ${ }^{30}$ In open field, parameters like number of square crossed, rearing rate(standing on hind limb) and time spent in central square are assessed for evaluating activity. ${ }^{31}$ Oral treatment of 7 consecutive day with ethanolic extract and on $8^{\text {th }}$ day, after $1 \mathrm{hr}$ of dosing, respective groups of animals showed increase in square crossed, number of rearing and time spent in central square as compared to the normal control group.

In summary, from the results of study it was confirmed that the ethanolic leaf extract of Tinospora cordifolia treated animal produced anxiolytic effect in dose dependent manner and at high dose $400 \mathrm{mg} / \mathrm{kg}$ showed significant anti-anxiety activity, when compared with normal control group.

\section{CONCLUSION}

Study was conducted to evaluate the ethanolic extract possess antianxiety activity. Presence of flavanoids, saponins and proteins are established by phytochemical analysis. The antianxiety potential was evaluated by elevated plus maze, light/dark transition test and open field test. It was found that ethanolic leaf extract of Tinospora cordifolia. Shows anxiolytic property in dose dependent manner. At a dose of $400 \mathrm{mg} / \mathrm{kg}$ showed significant increase in parameters compared with control treated group of animals; in open arm entries and time spent in open arm of elevated plus maze, number of entries into the light chamber and time spent in light chamber. In light/dark transition model; number of square crossed, rearing rate and time spent in Central Square in open field. From the results, it is confirmed that ethanolic extract possess significant antianxiety property and it can be used as anxiolytic agents. 


\section{CONFLICT OF INTEREST}

The authors declare that there is no conflict of interest.

\section{REFERENCES}

1. Craig C, Stitzel R. Modern pharmacology with clinical applications. $6^{\text {th }}$ edn Philadelphia: Lippincott Williams and Wilkins; 2004

2. Walker R. Whittleseac. Clinical pharmacy and therapeutics. 5th ed. New York: Churchill Livingstone; 2012.

3. Kandola A, Vancampfort D, Herring M, Rebar A, Hallgren M, Firth J, et al. Moving to beat anxiety: Epidemiology and therapeutic issues with physical activity for anxiety. Curr Psychiatry Rep. 2018;20(8):63. doi: 10.1007/s11920018-0923-x, PMID 30043270.

4. Kim J, Gorman J. The psychobiology of anxiety. Clin Neurosci Res. 2005;4(5-6): 335-47. doi: 10.1016/j.cnr.2005.03.008.

5. Shri R. Anxiety: Causes and management. J Behav Sci. 2010;5(1):100-18.

6. Brunton L, Goodman L, Hilal Dandan R. The Goodman and Gilman's manual of pharmacology and therapeutics. $5^{\text {th }}$ ed. New York: McGraw-Hill Medical; 2014.

7. Louvet S, Ischayek M, Danoff R. The current role of long-term benzodiazepines for the treatment of generalized anxiety. Osteopath Fam Phys. 2015;7(1):19-25.

8. Greenstein B, Greenstein. A Color atlas of neuroscience. 1st ed. Stuttgart: Thieme Verlag; 2002.

9. Kawlni L, Upadhayay S, Mukherjee K. Comprehensive Pharmacology Review of Guduchi [Tinospora cordifolia (Willd.) Miers]. Journal of Drug Research in Ayurvedic Sciences. 2018;3(1):48-52. doi: 10.5005/jp-journals-10059-0035.

10. Kaur G, Singh A, Singh C, Alam F, Kumar Gautam G. Phytochemical investigation of Tinospora cordifolia. Int J Pharm Nat Med.2014;2(1):98-101.

11. Mittal J, Mohan Sharma M, Batra A. Tinospora cordifolia: A multipurpose medicinal plant- A review. J Med Plants Stud. 2014;2(2):32-47.

12. Pathan A. Review on Tinospora cordifolia. Int J Pharm Drug Anal. 2017;5(8):310-2.

13. Garg P, Garg R. Qualitative and quantitative analysis of leaves and stem of Tinospora cordifolia in different solvent extract. J Drug Delivery Ther. 2018:8(5-s): 259-64. doi: 10.22270/jddt.v8i5-s. 1967.

14. Kokate CK, Purohit PA, Gokhale BS. Pharmacognosy. $48^{\text {th }}$ ed. Pune: Nirali Prakashan; 2013.

15. Vieira LFdA, Reis MDdS, Brandão ARA, Viana IMMN, Da Silva JP, Barreto E, et al. Anxiolytic-like effect of the extract from Bowdichia virgilioides in mice. Revista Brasileira de Farmacognosia. 2013;23(4):680-6. doi: 10.1590/S0102695X2013005000044.

16. Thippeswamy BS, Mishra B, Veerapur VP, Gupta G. Anxiolytic activity of Nymphaea alba Linn. in mice as experimental models of anxiety. Indian $J$ Pharmacol. 2011;43(1):50-5. doi: 10.4103/0253-7613.75670, PMID 21455422.

17. Dutt V, Dhar VJ, Sharma A. Antianxiety activity of Gelsemium sempervirens. Pharm Biol. 2010:48(10):1091-6. doi: 10.3109/13880200903490521, PMID 20860436 .
18. Peng WH, Hsieh MT, Lee YS, Lin YC, Liao J. Anxiolytic effect of seed of Ziziphus jujuba in mouse models of anxiety. J Ethnopharmacol. 2000;72(3):435-41. doi: 10.1016/s0378-8741(00)00255-5, PMID 10996283.

19. Gerhard H Vogel. Drug Discovery and Evaluation: Pharmacological assays. $2^{\text {nd }}$ ed.Germany.Springer; 2008.

20. Patil VP, Nanjappaiah HM, Chandrashekhar VM, Mucchandi IS, Hugar S, Kalyane NV. Evaluation of anti-anxiety activity of Anacyclus pyrethrum. Int Res J Pharm. 2018;8(12):46-9. doi: 10.7897/2230-8407.0812249.

21. Souto-Maior FN, De Carvalho FL, De Morais LC, Netto SM, De Sousa DP, De Almeida RN. Anxiolytic-like effects of inhaled linalool oxide in experimental mouse anxiety models. Pharmacol Biochem Behav. 2011;100(2):259-63. doi 10.1016/j.pbb.2011.08.029, PMID 21925533

22. Sheela D, Srinivasan V, Sukumar E. Anxiolytic effect of ethanolic extract of flowers of Chrysanthemum indicum in albino mice. Int J Pharm Sci Res. 2017;8(6):2573-7.

23. Barua CC, Talukdar A, Begum SA, Borah P, Lahkar M. Anxiolytic activity of methanol leaf extract of Achyranthes aspera Linn in mice using experimental models of anxiety. Indian J Pharmacol. 2012:44(1):63-7. doi: 10.4103/02537613.91869, PMID 22345872.

24. Ali Ahmed F, Sharmin Bristy R, Jahan Tasnova N. Ethnomedicinal practice of Tinospora cordifolia (Willd.) Meirs ex Hook f. and Thoms. by the traditional medicine practitioners at Savar, Dhaka. Jahangirnagar Univ J Biol Sci. 2015;4(2):47-51.

25. Robert G, Drapier D, Bentué-Ferrer D, Renault A, Reymann JM. M. J. B. B. R Acute and chronic anxiogenic-like response to fluoxetine in rats in the elevated plus-maze: Modulation by stressful handling. Behav Brain Res. 2011;220(2):344-8. doi: 10.1016/j.bbr.2011.01.051, PMID 21315769

26. Mahamuni S, Shenoy P, Nipate S, Bandawane D, Chaudhari P. Preclinical evaluation of anxiolytic agents: An overview. J Pharm Res Opin $2011 ; 1(2): 7-22$

27. Doukkali Z, Taghzouti K, Bouidida EL, Nadjmouddine M, Cherrah Y, Alaoui K Evaluation of anxiolytic activity of methanolic extract of Urtica urens in a mice model. Behav Brain Funct. 2015;11(1):19. doi: 10.1186/s12993-015-0063-y, PMID 25902868.

28. Saha A, Bose S, Banerjee S. Anti-anxiety activity of Amorphophallus paeoniifolius tuber in mice. J Pharm Res. 2013;6(7):748-52. doi: 10.1016/j.jopr.2013.07.018.

29. Manikkoth S, Damodar S, Sequeira M, Samuel K. Anti-anxiety activity of Eucalyptus tereticornis n-hexane extract in Wistar albino rats. Int $\mathrm{J}$ Basic Clin Pharmacol. 2017;6(3):577-80. doi: 10.18203/2319-2003.ijbcp20170816.

30. Elayaraja A, Abdul Rahaman S, Prem Kumar P, Radha Krishnan M. Antianxiety activity of hydro alcoholic extract of Scoparia dulcis Linn. assessed using different experimental anxiety models in rodents. Int J Pharmacol Res. 2015;5(3):62-7.

31. Mahendra P, Bisht S. Anti-anxiety activity of Coriandrum sativum assessed using different experimental anxiety models. Indian J Pharmacol. 2011;43(5):574-7. doi: 10.4103/0253-7613.84975, PMID 22022003.

Article History: Received: 05-08-2021; Revised: 08-10-2021; Accepted: 01-01-2022

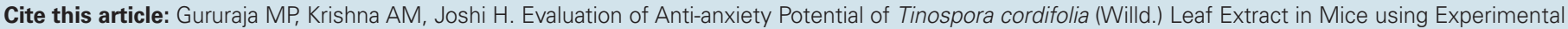
Models. J Young Pharm. 2022;14(1):46-9 